\title{
Performance of Food Waste Feeding Pilot Plant Biodigester Operated with Identified Potential Substrate Properties
}

\author{
Siti Hajar Yahaya ${ }^{1}$, Syafi'ah Nadiah Mohd Said ${ }^{1}$, Mohd Azhar Zain ${ }^{\mathbf{1}}$, \\ Mohammed Shahrir Mohamad Zahari ${ }^{1}$, Noor Azrimi Umor ${ }^{2}$, S. B. Ismail ${ }^{*}$ \\ ${ }^{1}$ Faculty of Ocean Engineering Technology and Informatics, \\ University Malaysia Terengganu, 21030 Kuala Nerus, Terengganu, MALAYSIA \\ ${ }^{2}$ Faculty of Applied Sciences, \\ UiTM Negeri Sembilan, Pekan Parit Tinggi, 72000 Kuala Pilah, Negeri Sembilan, MALAYSIA
}

*Corresponding Author

DOI: https://doi.org/10.30880/ijie.2021.13.03.003

Received 22 September 2020; Accepted 09 March 2021; Available online 01 June 2021

\begin{abstract}
Anaerobic digestion has been proven as sustainable process technology for organic waste conversion into renewable bio-energy. This study was conducted to evaluate the performance of mono-digestion process for different types of food waste substrates using pilot scale anaerobic bio-digester $(1200 \mathrm{~L})$ in terms of biogas production and the chemical oxygen demand (COD) removal efficiency. The biochemical methane potential (BMP) test of rice waste (R), vegetable waste (VW) and coconut meat residue (CMR) were tested at initial volatile solid (VS) loading of $0.1631,1.1690,1.0059 \mathrm{~g} \mathrm{VS} / \mathrm{L}$, respectively at fixed inoculum/substrate (I/S) ratio of 0.5 . Further study conducted by using rice waste (R) in pilot plant anaerobic bio-digester (1200L) for 43 days to investigate the reactor performance in term of COD removal efficiency. Interestingly, inoculum used for this study performs very well and able to digest food waste. Results demonstrate that the maximum specific biogas yield (SBY) was observed from rice waste (R) at $0.0587 \mathrm{~L} / \mathrm{kg}$ VS compared to other substrates. Specific biogas yield (SBY) of rice waste (R) was $16.01 \%$ and $11.92 \%$ higher than substrate vegetable waste (VW) and coconut meat residue (CMR) respectively. High COD removal efficiency of pilot plant bio-digester (up to $93 \%$ ) using rice waste (R) as sole substrate indicates a good performance of reactor in treating food waste. Conversion of food waste to biogas in pilot plant bio-digester is highly potential as one of the sustainable waste treatment technology
\end{abstract}

Keywords: Anaerobic digestion, biomethane potential, biogas, food waste, inhibition effects, methane

\section{Introduction}

One of the highest wastes generated in Malaysia is food waste, which contributes to about $31 \%$ to $45 \%$ of the total volume generated every day [1]. This waste commonly would be disposed of into landfills that could lead to the emission of greenhouse gas. Thus, to prevent this problem, an alternative method, such as anaerobic digestion, can be used since it is considered to be an economical and environmentally friendly technology [2].

In this study, the conversion of food waste to biogas was attempted in a pilot-scale anaerobic digester. Anaerobic digestion is a process where the organic materials are being digested by the microorganisms in the absence of oxygen to produce biogas. This biogas mainly consists of methane and carbon dioxide. Biogas can be directly used either for combustion or turned into electricity. Inside the digester, the food waste substrate will undergo the following stages: 
hydrolysis, acidogenesis, acetogenesis, and methanogenesis. However, these processes are influenced by some physical and chemical parameters such as the total solids content (TS), the volatile solids content (VS), carbon and nitrogen ratio $(\mathrm{C} / \mathrm{N})$, particle size, temperature, $\mathrm{pH}$, inoculum type, and co-digestion with other organic wastes (i.e., animal manure, sewage sludge, waste from the food industry) [3]. These all parameters are assessed in terms of biodegradability; the decomposition rate by the anaerobic processes.

One of the most relevant tests for assessing the biodegradability as it gives significant information about the biomethanation of specific substrates and provides experimental results essential to calibrate and validate mathematical models is biochemical methane potential analysis [4]. [5] stated that biodegradability assays are based on the measurement of either formation of one or more products involved in the biological reaction under investigation or measurement for substrate depletion. While for methods based on substrate depletion can be determined either as a lumped parameter (volatile solids (VS), chemical oxygen demand (COD), dissolved organic carbon (DOC), etc.) or directly analysis of the compound that is being used as a substrate [6]. As the biodegradability of substrate increases, the biomethanation rate also increases [4].

However, the inhibition factor may arise during the process. The inhibitors commonly present in anaerobic digesters include ammonia, sulfide, light metal ions, heavy metals, and organics [7]. Furthermore, the AD of food waste usually results in process inhibition due to the rapid accumulation of VFAs [8] and ammonia [9]. To maintain stable operation, the digesters are usually operated at a low organic loading rate (OLR) [10] or by mixing with sewage sludge, which has high $\mathrm{C} / \mathrm{N}$ and low biodegradability [11].

Currently, the pilot-scale anaerobic digestion of different types of food waste has been studied extensively. [12] used $50 \mathrm{~L}$ digester for the anaerobic digestion of food waste (rice) at $35{ }^{\circ} \mathrm{C}$ with the mixing volume ratio of food waste to water was 1:1 in which resulted 95.3 and 123 liters of total cumulative biogas produced on the last day 20th for the non-inoculated and inoculated samples respectively. Meanwhile, the daily volume of biogas yield for anaerobic digestion of rice food waste was highest at day 18th with value of $10.2 \mathrm{~L}$ and $12.3 \mathrm{~L}$ for the non-inoculated and inoculated samples respectively. At the same time, a study from [13] used $70 \mathrm{~L}$ pilot-scale digester for anaerobic digestion of vegetable waste at $34{ }^{\circ} \mathrm{C}$ with a fixed hydraulic retention time of 25 days. The highest biogas production is $0.4 \mathrm{~m} 3 / \mathrm{kg}$ VS $(33.3 \mathrm{~L} / \mathrm{d})$ with suggested OLR of $1.4 \mathrm{~kg} \mathrm{VS} / \mathrm{m}^{3} . \mathrm{d}$. Anaerobic digestion of food waste is achievable. However, different types of food waste result in varying degrees of methane yield. Thus, the effects of mixing various types of food waste and their proportions should be determined on a case by case basis [12].

This study was embarked to evaluate the performance of mono digestion for different types of food waste substrates in pilot-scale anaerobic biodigester $(1200 \mathrm{~L})$ in terms of biogas production and the chemical oxygen demand (COD) removal efficiency.

\section{Materials and Methodology}

\subsection{Preparation of Substrates and Inoculum}

The substrates that were used in this research are rice, vegetable waste, and coconut meat residue from a wet market in Kuala Terengganu, Terengganu. The inoculum is taken from the existing palm oil mill digester and stored in the refrigerator at $4{ }^{\circ} \mathrm{C}$. Each sample was blended with distilled water with a ratio of 1: 0.2, 1: 2, and 1: 1, respectively. The blended samples are used in biochemical methane potential (BMP) assay to determined their biodegradability potential and physicochemical analysis to determine the total solid (TS), volatile solids (VS), chemical oxygen demand (COD) and soluble chemical oxygen demand (sCOD) for each sample.

\subsection{Biomethane Potential (BMP) Assay}

The biochemical methane potential (BMP) assay was done in triplicate for each sample and a blank. Serum bottles $(125 \mathrm{ml})$ are flushed with nitrogen gas for 2 minutes. The substrates and inoculum are filled with a ratio of 2:1 for each sample. S/I ratio stated in Table 1 below was calculated based on $\mathrm{g}$ VS basis. In order to standardize the working volume of reactor used, the volume of substrates and volume of inoculum in term of Liters (L) have been fixed but the value of Volatile Solid (VS) for each substrate are different, hence the S/I ratio also tun into different. Phosphate buffer $(700 \mu \mathrm{l})$, micronutrients $(42 \mu \mathrm{l})$ and macronutrients $(420 \mu \mathrm{l})$ are added into the mixture as supplements based on the nutrient list from [14]. Distilled water is added until the volume reached $70 \mathrm{ml}$. Then, the serum bottles are flushed again with nitrogen gas and immediately sealed with the rubber cover provided with the bottle. The serum bottles are incubated at $37^{\circ} \mathrm{C}$.

In order to measure the amount of biogas produced in each serum bottle, a $20 \mathrm{ml}$ syringe is inverted straight into the lid of each serum bottle. The serum bottles are shaken once to twice a day. The reading of biogas volume for each bottle is recorded daily and the experiment are terminated after the volume of the biogas did not increase. Table 1 below shows the experimental setup for the biochemical methane potential (BMP) test of different substrates. 
Table 1 - Experimental setup for Biochemical Methane Potential (BMP) test of different substrates

\begin{tabular}{lccc}
\hline Parameter & $\begin{array}{c}\text { Rice waste } \\
(\mathbf{R})\end{array}$ & $\begin{array}{c}\text { Vegetable Waste } \\
(\mathbf{W V})\end{array}$ & $\begin{array}{c}\text { Coconut Meat Residue } \\
\text { (CMR) }\end{array}$ \\
\hline Operation Conditions & & & \\
\hline No. of replications & 3 & 3 & 3 \\
Reactor working volume (m) & 125 & 125 & 125 \\
Mass substrates (g VS/L) & 0.1631 & 1.1690 & 1.0059 \\
Volume substrates (L) & 0.0140 & 0.0140 & 0.0140 \\
Mass inoculum (g VS/L) & 1.1285 & 1.1285 & 1.1285 \\
Volume inoculum (L) & 0.0070 & 0.0070 & 0.0070 \\
S/I (g VS) & 0.2891 & 2.0718 & 1.7827 \\
\hline Characteristics & & & 7.12 \\
\hline Initial pH & 7.52 & 6.49 & 6.07 \\
Final pH & 6.74 & 5.33 & 47,300 \\
Initial COD (mg/L) & 212,300 & 59,600 & 41,700 \\
Final COD (mg/L) & 26,700 & 49,300 & \\
\hline
\end{tabular}

\subsection{Reactor Setup}

Next, for the pilot plant performance of a substrate chosen, a $1.2 \mathrm{~m}^{3}$ reactor is used. In this reactor, the weight ratio of substrate to inoculum is $2: 1$ since the substrate that have been chosen from BMP assay was rice waste. The experiment is carried out for about 43 days. The substrate is being fed once in a week into the reactor and the COD of the effluent from the anaerobic digestion process is analysed and recorded daily. From the COD value, the value of COD removal is calculated. Fig. 1 shows the diagram of the anaerobic digester set up.

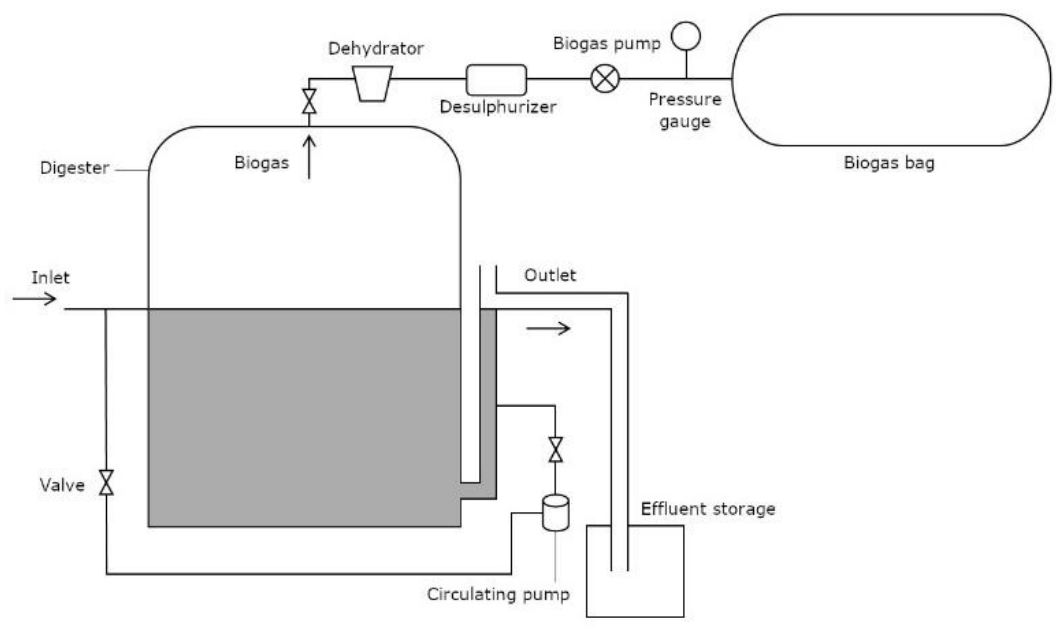

Fig. 1 - Anaerobic digester set up

\subsection{Other Analysis}

For the characterization of substrates and inoculum samples, the samples were analyzed for their $\mathrm{pH}$, total solids (TS), volatile solids (VS), volatile fatty acid (VFA), and chemical oxygen demand (COD). Total solids (TS), volatile solids (VS), pH, volatile fatty acid (VFA), chemical oxygen demand (COD), and soluble chemical oxygen demand (SCOD) analysis were carried out according to standard methods [15].

\section{Results and Discussion}

\subsection{Characterization of different substrates and Inoculum}

A key parameter of designing and operating anaerobic reactors is the characteristics of feedstock, which strongly affect the biogas yield and anaerobic process stability. The initial physicochemical characteristics of inoculum and substrates in this study including analysis of total solid (TS), volatile solids (VS), chemical oxygen demand (COD), pH and volatile fatty acid (VFA) were summarized in Table 2 and Table 3, respectively. From the data in Table 2, inoculum (I) was at $\mathrm{pH}$ 6.58, which is within the optimum range for anaerobic digestion (AD) process [5]. It also can 
be seen that inoculum (I) has a very low range of VFA concentration which is $109.60 \mathrm{mg} / \mathrm{L}$, in which as reported by [16] in their previous study that the value of VFA within the optimum range (173-193 mg/L) did not cause inhibition during digestion period since most of VFAs produced were consumed by methanogens.

Table 2 - The characteristics of inoculum used in this research

\begin{tabular}{lccccc}
\hline & pH & $\begin{array}{c}\text { \% Total } \\
\text { Solid (g/L) }\end{array}$ & $\begin{array}{c}\text { \% Volatile } \\
\text { Solid (g/L) }\end{array}$ & $\begin{array}{c}\text { Volatile Fatty } \\
\text { Acids (VFA)* }\end{array}$ & $\begin{array}{c}\text { Chemical Oxygen } \\
\text { Demand (COD) }\end{array}$ \\
\hline Inoculum (I) & 6.58 & 1.28 & 55.81 & 109.60 & $40,600 \mathrm{mg} / \mathrm{L}$ \\
\hline
\end{tabular}

Based on $\mathrm{mg} / \mathrm{L}$ acetic acid equivalent [HAceq]

Results from Table 3 shows that coconut meat residue (CMR) contained the highest percentage of TS, which is at $7.32 \%$, followed by $7.02 \%, 2.40 \%$, and $1.28 \%$ for rice $(\mathrm{R})$, vegetable waste $(\mathrm{VW})$ and inoculum (I) respectively. Interestingly, substrate rice $(\mathrm{R})$ has the highest percentage of VS compared to coconut meat residue (CMR) and the other two substrates and inoculum. The percentage of VS for rice (R), vegetable waste (VW), coconut meat residue (CMR), and inoculum (I) are at 95.35\%, 81.81\%, 14.02\%, and 55.81\% respectively. According to [17] value of total TS and VS of substrates can be used to predict the anaerobic digestion process efficiency and biogas yield. Hence, the value of VS for substrate rice $(\mathrm{R})$ portrays that rice waste $(\mathrm{R})$ has a high potential to produce a huge amount of biogas production in the anaerobic digestion (AD) process.

The data presented in Table 3 shows that coconut meat residue has the lowest COD concentration, which is at $10,700 \mathrm{mg} / \mathrm{L}$ compared to substrate rice $(165,300 \mathrm{mg} / \mathrm{L})$ and vegetable waste $(21,300 \mathrm{mg} / \mathrm{L})$. Surprisingly, substrate rice $(\mathrm{R})$ has the highest percentage of $\mathrm{SCOD} / \mathrm{COD}$ but has the lowest percentage of VS/TS. According to [18], soluble chemical oxygen demand (sCOD) used to analyze the amount of soluble organic material in the subjected substrate and express the readiness of materials to be converted into methane through the AD process. Therefore, the high percentage of sCOD/COD of substrate rice waste $(\mathrm{R})$ supports the finding reported by [19], in which the highest value of COD solubilization would significantly affect the biogas production.

Table 3 - The characteristics of different substrates used in this research

\begin{tabular}{lccc}
\hline Parameter & Rice (R) & Vegetable Waste (VW) & Coconut Meat Residue (CMR) \\
\hline $\mathrm{pH}$ & 6.34 & 5.88 & 6.08 \\
Total Solid (g/L) & 17.55 & 32.14 & 14.58 \\
\% Total Solid (g/L) & 7.02 & 2.40 & 7.32 \\
Volatile Solid (g/L) & 0.8155 & 5.85 & 5.03 \\
\% Volatile Solid (g/L) & 95.35 & 81.81 & 14.02 \\
\% VS/TS (g/l) & 5 & 18 & 34 \\
COD (mg/L) & 165,300 & 21,300 & 10,700 \\
sCOD (mg/L) & 112,380 & 11,200 & 4,010 \\
sCOD/COD (\%) & 67.99 & 52.58 & 37.48 \\
\hline
\end{tabular}

\subsection{Biogas Generation from Biomethane Potential (BMP)}

Table 4 shows the overall performance of BMP of different substrates. Fig. 2 shows the cumulative and specific biogas yields of three substrates in mono digestion of the BMP setup. Biogas values presented are the average results of triplicate trials at standard temperature and pressure after control correction.

Table 4 - Biomethane Potential (BMP) performance of different substrates

\begin{tabular}{lccc}
\hline Parameter & Rice (R) & Vegetable Waste (WV) & Coconut Meat Residue (CMR) \\
\hline Time (Days) & 7 & 7 & 8 \\
Cumulative Biogas Production (mL) & 76 & 22 & 15 \\
Specific biogas yield (L/kg VS) & 0.0587 & 0.0094 & 0.0007 \\
COD removal (\%) & 87.42 & 17.28 & 11.84 \\
\hline
\end{tabular}

Under the optimal ratio of substrate/inoculum (S/I) of 0.2891 with a total organic load of $1.2916 \mathrm{~g}$ VS/L, the highest cumulative biogas production (CBP) reached $76 \mathrm{~mL} /$ day when substrate rice was placed in serum bottle of BMP to undergo the process of mono digestion for 7 days. The specific biogas yields (SBY) of three substrates of rice $(\mathrm{R})$, vegetable waste (VW), and coconut meat residue (CMR) were 0.0587, 0.0094, and 0.0007 L/kg VS respectively. The mono digestion of rice $(\mathrm{R})$ had the highest cumulative and specific biogas yield among all, while substrate coconut meat residue (CMR) yielded the lowest biogas (Fig. 2). Specific biogas yield (SBY) of rice (R) was 16.01 and $11.92 \%$ 
higher than substrate vegetable waste (VW) and coconut meat residue (CMR), respectively. The value of COD removal $(\%)$ for mono digestion of substrate rice (R) is the highest among all which is $87.42 \%$ and it shows the ability of the substrate to lower down the COD influent of $212,300 \mathrm{mg} / \mathrm{L}$ to $26,700 \mathrm{mg} / \mathrm{L}$ after the end of 7 days digestion periods.

Specific biogas yield (SBY) and cumulative biogas production (CBP) was the highest from substrate rice (R), as it has the highest percentage of VS and the highest percentage of sCOD/COD. Meanwhile, the lowest of Specific biogas yield (SBY) and cumulative biogas production (CBP) is from substrate coconut meat residue (CMR). It can be seen from the collected data in Table 3 that coconut meat residue (CMR) has a low percentage of TS. Thus, these results confirmed the finding reported by [20] mentioned that coconut meat residue (CMR) found to have a high percentage of moisture content due to the high water-holding capacity, water retention, and swelling capacity of itself compared to other dietary fibers. The high percentage of VS/TS of coconut meat residue (CMR) indicates that the fast degradation of VS, which leads to rapid acidification and VFAs accumulation, hence resulted in lower down the cumulative biogas production (CBP).

Furthermore, according to [21] there is about 17-24\% of extractable oil content found in coconut meat residue (CMR) after coconut milk extraction. This result may explain the reason behind the lowest cumulative biogas production (CBY) from coconut meat residue (CMR) due to the high loading of lipids, which resulted in a decrease in the degradation of carbohydrates and protein. High lipids lead to process failure by the formation of oil floc and absorption to microbial cells that affect the methanogen activity and biogas production. However, few parameters may affect the biogas production such as $\mathrm{C} / \mathrm{N}$ ratio, $\mathrm{pH}$ instead of the effect of lipid content in the substrate itself [22].
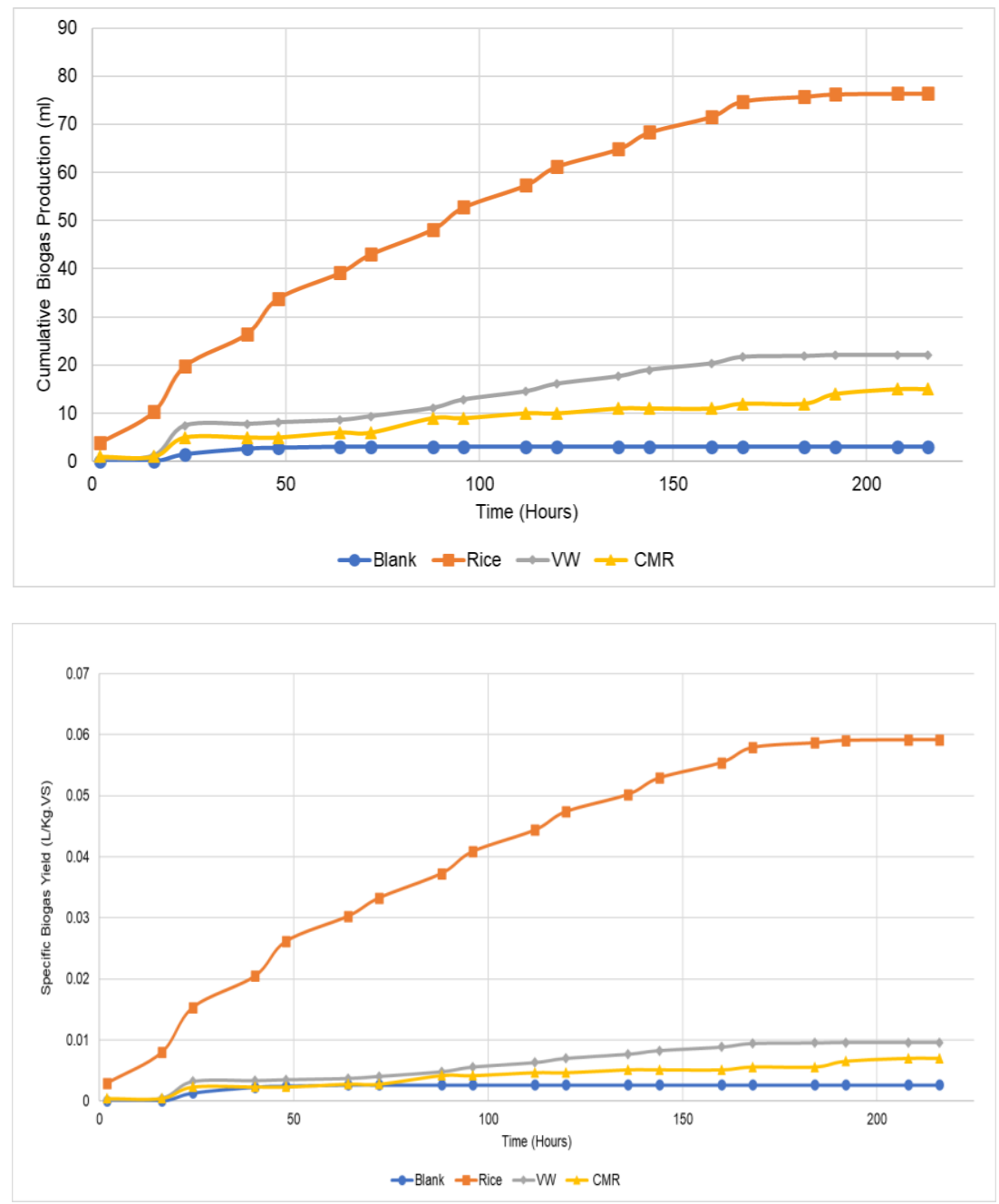

Fig. 2 - Cumulative (top) and specific biogas yields (below) of substrate mixtures during BMP test

\subsection{Reactor Performance: COD Removal Efficiency (\%) of Substrate Rice Waste (R)}

Overall, reactor performance in terms of COD removal efficiency of mono digestion substrate rice (R) is illustrated in Fig. 3. Three substrates of rice (R), vegetable waste (VW), and coconut meat residue (CMR) were analyzed in the biomethane potential (BMP) test in order to evaluate the potential of each substrate to produce biogas. It has been observed that substrate rice $(\mathrm{R})$ had the highest cumulative and specific biogas yield among all of the two other 
substrates. According to [23] common operational issues for the anaerobic digestion (AD) of food waste is process instability, hence microbial management, process monitoring, and control were used to overcome the instability and increase the energy conversion efficiency of anaerobic digesters.

As shown in Table 5, the COD concentration of influent and effluent in the reactor on the $0^{\text {th }}$ day is about 32,000 $\mathrm{mg} / \mathrm{L}$, which resulted in $0 \%$ of COD removal efficiency. The feeding of rice waste for the reactor is started on the $1^{\text {st }}$ day of the digestion period, with about $165,000 \mathrm{mg} \mathrm{COD} / \mathrm{L}$. The circulation system of the reactor is operated once the loading of rice waste to determine the mixture homogeneity of substrate and inoculum. On the next day, the COD concentration of effluent is decreasing from 165,000 to $64,000 \mathrm{mg} / \mathrm{L}$, which indicates the positive result of COD removal efficiency, in which about $68 \%$ of COD from the reactor is successfully removed.

The reactor was not fed with rice waste until day $7^{\text {th }}$ of digestion period and as can be seen in Fig. 3, there has been a steep fall of COD effluent concentration. The same amount of COD concentration of rice waste was fed on day $8^{\text {th }}$ and the trends shows the similar result as in day $1^{\text {st }}$ of digestion period. The COD removal efficiency drop to $64 \%$ due to increasing of COD influent concentration on the feeding day but simultaneously there are gradually drop of COD effluent concentration from day $9^{\text {th }}$ to day $14^{\text {th }}$, in which it is a good indicator of reactor performance.

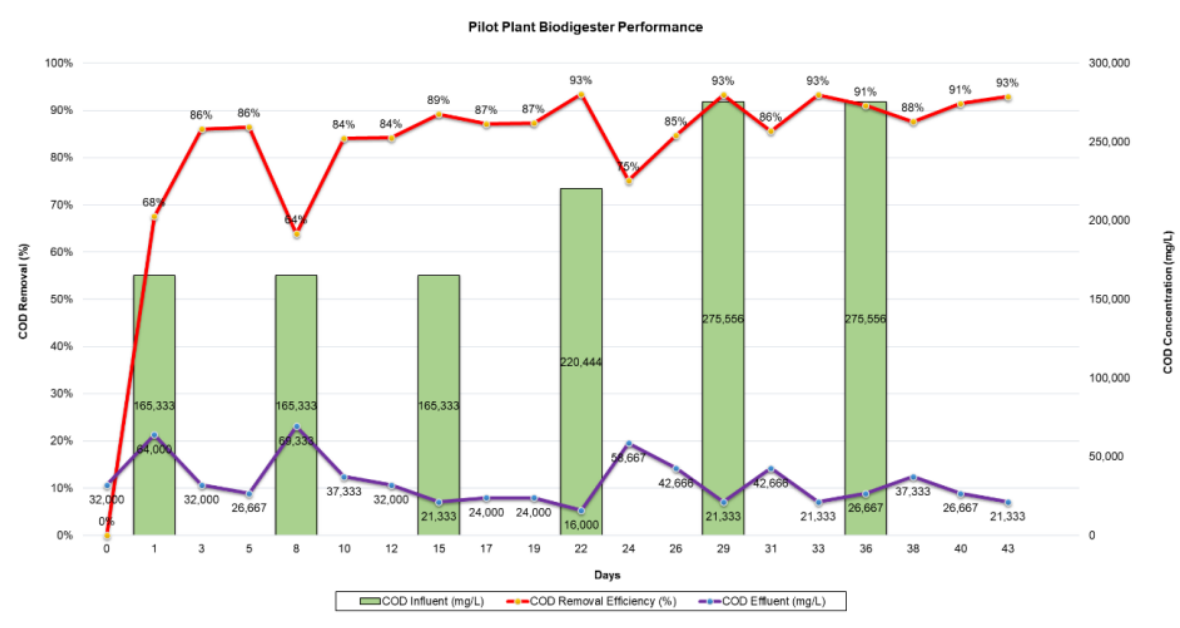

Fig. 3 - COD removal Efficiency (\%) of substrate rice (R)

Table 5 - COD Removal Efficiency (\%) of $1.2 \mathrm{~m}^{3}$ reactor Anaerobic Digestion (AD)

\begin{tabular}{cccc}
\hline Days & $\begin{array}{c}\text { Influent COD } \\
\text { concentration }(\mathbf{m g} / \mathbf{L})\end{array}$ & $\begin{array}{c}\text { Effluent COD } \\
\text { concentration* }(\mathbf{m g} / \mathbf{L})\end{array}$ & $\begin{array}{c}\text { COD Removal } \\
\text { Efficiency }(\%)\end{array}$ \\
\hline 0 & 32,000 & 32,000 & 0 \\
$1^{\text {st }}$ & 165,300 & 64,000 & 68 \\
$8^{\text {th }}$ & 165,300 & 69,300 & 64 \\
$15^{\text {th }}$ & 165,300 & 21,300 & 89 \\
$22^{\text {nd }}$ & 220,400 & 16,000 & 93 \\
$29^{\text {th }}$ & 275,500 & 21,300 & 93 \\
$36^{\text {th }}$ & 275,500 & 26,600 & 91 \\
$43^{\text {rd }}$ & - & 21,300 & 93 \\
\hline$*$ Effluent COD concentration was taken the next day after each new feeding/influent addition
\end{tabular}

The third time of feeding is on day $15^{\text {th }}$ with the same amount of COD concentration of rice waste. Previous trend shows a day after feeding there will be increasing of COD removal efficiency which indicate the good performance of reactor but surprisingly the third feeding result does not show the same trend as previous. The COD removal efficiency keep increasing even though there are new loading of rice waste, thus decreasing the COD concentration of effluent on the next day. This finding indicates that the consortium of microbes in the reactor system have possibility to digest more higher concentration of rice waste and the reactor did not reach its maximum performance yet. Hence, the new COD concentration of rice waste was introduced into the reactor on the day $22^{\text {nd }}$.

As can be seen in Fig. 3, the COD removal efficiency on the feeding day of $22^{\text {nd }}$ increasing from $87 \%$ to $93 \%$ thus lowered the reading of COD effluent on the next day again. Interestingly, this result shows that microbes in the reactor actively digest the organic substrates hence, the higher COD concentration of rice waste was introduced on the next feeding day. As have been expected, the trend remains the same until the feeding day on $29^{\text {th }}$ in which it is the good 
indicator of stability of the anaerobic digestion $(\mathrm{AD})$ in the reactor. Strong evidence of the hypothesis was found when there is a slightly increasing COD removal efficiency even after introducing a new COD concentration of influent. As the result, the COD concentration of effluent gradually decrease over the time.

A similar COD concentration of rice waste, $275556 \mathrm{mg} / \mathrm{L}$ was fed in the reactor on day $36^{\text {th }}$ and the result shows there is slightly fall of COD removal efficiency from $93 \%$ to $91 \%$ on the feeding day. This result can be seen as in the first phase of feeding period specifically on day $8^{\text {th }}$ which the COD removal efficiency drastically fall right on the feeding day. This situation explains how the stability of anaerobic digestion process occurred in the reactor. In conclusion, the stability of the $\mathrm{AD}$ process in $1.2 \mathrm{~m}^{3}$ reactor during digesting the substrate rice waste $(\mathrm{R})$ can be reached up to $93 \%$ of efficiency in order to remove the maximum COD concentration of $275,556 \mathrm{~g} \mathrm{COD} / \mathrm{L}$ of rice.

\section{Conclusions}

The following conclusions can be drawn from the present research:

- The inoculum used for this study performs very well and seems does not give any effect digesting food waste from palm oil mill effluent.

- $\quad$ Specific biogas yield (SBY) and cumulative biogas production (CBP) was the highest from substrate rice (R) at $0.0587 \mathrm{~L} / \mathrm{kg} \mathrm{VS}$ and $76 \mathrm{~mL}$, respectively, compared to other substrates.

- High COD removal efficiency of pilot plant bio-digester (up to $93 \%$ ) using rice (R) as the sole substrate.

- Best on this excellent performance, mono-digestion of food waste (Rice) give promising results for the operation of bio-digester.

\section{Acknowledgement}

The authors wish to thank Universiti Malaysia Terengganu under Knowledge Transfer Assimilation Grant Scheme (KTAGS) (Project code: 58902) for financially supported this research and the excellent technical support during analytical works from Ismafatin Nabilah Ismail and Nur Qistina Izzati Kamarulzaman.

\section{References}

[1] JPSPN (2012). Food Waste Management Development Plan for Industry, Commercial and Institution Sector. National Solid Waste Management Department, Ministry of Housing and Local Government

[2] Hanum F., Yuan L. C., Kamahara H., Aziz H. A., Atsuta Y., Yamada T. \& Daimon H. (2019). Treatment of sewage sludge using anaerobic digestion in Malaysia: Current State and Challenges. Frontiers in Energy Research, https://doi.org/10.3389/fenrg.2019.00019

[3] Stan C., Collaguazo G., Streche C., Apostol T. \& Cocarta D. (2018). Pilot-scale anaerobic co-digestion of the OFMSW: Improving biogas production and startup. Sustainability, 10(6), 1939

[4] Hussain A. \& Dubey S. K. (2015). Specific methanogenic activity test for anaerobic degradation of influents. Applied Water Science, 7(2), 535-542

[5] Angelidaki I., \& Sanders W. (2004). Assessment of the anaerobic biodegradability of macropollutants. Reviews Environmental Science and Biotechnology, 3, 117-129

[6] Rozzi A. \& Remigi E. (2001). Anaerobic biodegradability. In the 9th World Congress, Anaerobic Digestion 2001, Belgium

[7] Chen Y., Cheng J. J. \& Creamer K. S. (2008). Inhibition of anaerobic digestion process: A review. Bioresource Technology, 99(10), 4044-4064

[8] Yong Z., Dong Y., Zhang X. \& Tan T. (2015). Anaerobic co-digestion of food waste and straw for biogas production. Renewable Energy, 78, 527-530.

[9] Wang P., Wang H., Qiu Y., Ren L. \& Jiang B. (2018). Microbial characteristics in anaerobic digestion process of food waste for methane production - A review. Bioresource Technology, 248, 29-36

[10] Tampio E., Ervasti S., Paavola T., Heaven S., Banks C. \& Rintala J. (2014). Anaerobic digestion of autoclaved and untreated food waste. Waste Management, 34(2), 370-377

[11] Kawai M., Nagao N., Tajima N., Niwa C., Matsuyama T. \& Toda T. (2014). The effect of the labile organic fraction in food waste and the substrate/inoculum ratio on anaerobic digestion for a reliable methane yield. Bioresource Technology, 157, 174-180

[12] Ofili I., Al Ali O. P., Emeka E. C., Ugwoke E.C. and Eze E. (2020). Biogas production from anaerobic digestion of food waste generated in Enugu Metropolis. Pacific Journal of Science and Technology, 21(1), 30-37

[13] Babaee A. \& Shayegan J. (2011). Anaerobic digestion of vegetable waste. Chemical Engineering Transactions, $24,1291-1296$

[14] Hussain A. \& Dubey S. K. (2013). Specific methanogenic activity test for anaerobic treatment of phenolic wastewater. Desalination and Water Treatment, 52(37-39), 7015-7025

[15] APHA (2005). Standard Methods for The Examination of Water and Wastewater. APHA 
[16] Haider M. R., Zeshan, Yousaf S., Malik R. N. \& Visvanathan C. (2015). Effect of mixing ratio of food waste and rice husk co-digestion and substrate to inoculum ratio on biogas production. Bioresource Technology, 190, 451457

[17] Orhorhoro E. K., Ebunilo P. O. \& Sadjere G. E. (2017). Experimental determination of effect of total solid (TS) and volatile solid (VS) on biogas yield. American Journal of Modern Energy, 3(6), 131-135

[18] Junoh H., Palanisamy K., Yip C. H. \& Pua F. L. (2015). Optimization of NaOH thermo-chemical pretreatment to enhance solubilisation of organic food waste by response surface methodology. International Journal of Chemical, Molecular, Nuclear, Materials and Metallurgical Engineering, 9(12), 1220-1226

[19] Li C., Champagne P. \& Anderson B. C. (2015). Enhanced biogas production from anaerobic co-digestion of municipal wastewater treatment sludge and fat, oil and grease (FOG) by a modified two-stage thermophilic digester system with selected thermo-chemical pre-treatment. Renewable Energy, 83, 474-482

[20] Ng S. P., Tan C. P., Lai O. M., Long K. \& Mirhosseini H. (2010). Extraction and characterization of dietary fiber from coconut residue. Journal of Food, Agriculture and Environment, 8(2), 172-177

[21] Sulaiman S., Abdul Aziz A. R. \& Aroua M. K. (2013). Reactive extraction of solid coconut waste to produce biodiesel. Journal of the Taiwan Institute of Chemical Engineers, 44(2), 233-238

[22] Bong C. P. C., Lim L. Y., Lee C. T., Klemeš J. J., Ho C. S. \& Ho W. S. (2018). The characterisation and treatment of food waste for improvement of biogas production during anaerobic digestion - A review. Journal of Cleaner Production, 172, 1545-1558

[23] Li L., Peng X., Wang X. \& Wu D. (2018). Anaerobic digestion of food waste: A review focusing on process stability.

Bioresource
Technology,
248(174),

$20-28$ 